\title{
A- Level Textile Technology and Design Curriculum Compatibility with Industry Requirements in Harare, Zimbabwe
}

\author{
Audrey Chirapa ${ }^{1}$ and Prof. Lois Ranganai Mberengwa, $\mathrm{PhD}^{2 *}$ \\ ${ }^{1}$ Chemhanza High School, Wedza, Zimbabwe \\ ${ }^{2}$ Midlands State University, Zimbabwe \\ *Corresponding Mail: mberengwal@staff.msu.ac.zw
}

\begin{abstract}
Through descriptive design, this study sought to establish the compatibility of the A-level Textile Technology and Design (TTD) curriculum with the industry requirements in Harare, Zimbabwe. The study employed both quantitative and qualitative techniques through a questionnaire and interview schedule. The population comprised of 120 A-level learners and five teachers from five schools as well as eight factory managers. Forty learners who had studied the subject for at least one year and teachers based on their experience in teaching were purposely selected to constitute the sample. Three factory managers from clothing industries in Harare City were conveniently selected based on their willingness to participate in the study. Data was treated through descriptive statistics and thematically. The study established that learners did not acquire adequate essential concepts in designing, pattern making, computer aided designing, use of industrial sewing equipment and business enterprise which are critical for business or employment in the clothing industry. Some study areas were found to be compatible with the requirements of the clothing industry and entrepreneurship, but the content was not well taught. Teachers were not proficient with new skills and knowledge in the updated syllabus. The majority of the learners was either neutral, disagreed or strongly disagreed to have acquired the intermediate skills related to the updated Textile Technology and Design Curriculum. Therefore, a more skills based curriculum is recommended. In-service training of TTD teachers in business and entrepreneurship skills is also recommended.
\end{abstract}

Keywords: Clothing industry, Textile Technology and Design, curriculum, entrepreneurship.

\section{Introduction}

The Government of Zimbabwe, through the Ministry of Primary and Secondary Education is making efforts to develop self-reliance skills among school children so that they are able to generate employment either for themselves or for others (Nkomo, 2016). The guiding framework of the curriculum is reflected in the Zimbabwe Agenda for Sustainable Socioeconomic Transformation (ZIMASSET, 2013) and forms part of the implementation of commission of enquiry into Education and Training led by Nziramasanga (1999). Its main thrust is to prepare learners to participate fully in the job market after completing High School.

According to Nkomo (2016) and Mlambo (2017), the updated curriculum was crafted to attain sustainable development and social equity driven by indigenizing, empowerment and employment creation. The problem of low industrial capacity utilization, high unemployment and rampant poverty needed to be addressed and this could be done through the innovative curriculum that also support entrepreneurship (Murwira, 2019). Marume (2012) observed that over the last two decades, there have been conversations in government, education system, non-governmental organizations, the business world and other social facets in Zimbabwe about the nature of the educational system. The conversation was focused around its shortfalls and on what could be changed or improved to produce individuals with ability to contribute meaningfully to the development of the country. The updated curriculum thus, takes into consideration the impact of information and communication technologies and their influence towards information driven economy and how 
these warrant new skill sets to enable citizens to live and work competitively in the global village.

Dale (2010) posits that the general world consensus is that technical education is associated with the purpose of making learners more able to selfsustain and become more aware of skills required in the world of work. This implies that learning areas similar to Textiles Technology and Design (TTD) have a role to play in developing learners with entrepreneurship skills so that learners can design, make and sell clothes using the acquired skills. Pearson (2003) concurs with Dale that practical learning areas like TTD play an important role in building capacity for learners to be abreast with the global changes in terms of contemporary designing and production systems. The updated Form Five to Form Six TTD curriculum thus aims at developing technical skills that will empower learners to be creative and innovative in the world of work. It further aims at developing life-long skills which include critical thinking, problem solving, independence and self-employment (Curriculum Development and Technical Services, 2015). TTD curriculum should therefore be compatible with the clothing and textile industry requirements.

In Zimbabwean schools, the new/updated Textiles Design and Technology syllabus is meant to develop entrepreneurship skills. This learning area covers both theoretical and practical aspects of TTD. The syllabus recognizes the use of TTD as a tool for inclusivity that encourages learners to appreciate diversity and differences. The learning area intends to develop learners of various social settings in the use of locally available resources in order to develop patriotism (Curriculum Development and Technical Services, 2015). It is further intended to empower the learners to function in the prevailing economy which is production oriented. The syllabus embraces the skills done in TTD in the quest for creating a high level of economic independence in Zimbabwe. Therefore, practical work is an integral and expected part of the learning area that requires scientific and investigative work (ibid, 2015).

According to the Association of Graduate Careers Advisory Services (Association of Graduate Careers Advisory Services) (2017), to work in the textile and clothing industry, one needs to have a high level of technical knowledge and strong practical skills in designing contemporary styles that will compete at the international market. The ability to work as part of a team and to liaise with colleagues in other garment production functions also requires collaboration. Strong negotiating skills are required when doing market research and advertising one's designs to retailers, companies, suppliers of raw materials and schools. This concurs with Olokocha (2012) who argues that there is need to produce high school graduates who are innovative and adaptable to the changes of the manufacturing industry. Problem-solving and decision-making skills are therefore useful especially when trying to change the design which has not been well accepted by customers and when developing good merchandising skills.

Stevenson (2012) defines entrepreneurship as the ability to start up and form self-employment after acquiring skills from elementary school curriculum. This implies that learners should be equipped with entrepreneurship skills that will enable them to survive on the job market after leaving school. For example, A-level learners studying TTD should be able to start up clothing companies and introduce their own designs and patterns on the market basing on the skills acquired in school. Such skills should enable them to innovate and improve designs already existing in the market. Also, learners should be able to attain employment in the clothing sector with minimum training and supervision.

The A-level TTD curriculum includes entrepreneurial skills of relative importance and usefulness in the textile industry. These include being acquainted with the use of basic software used in the designing of textiles products and making patterns (Aldrich, 2015). For example, entrepreneurs are expected to produce designs that can compete on the international market using software which is very fast and be able to edit the designs. Dickerson (2003) supports the idea that learners should develop skills in identifying properties of fibres so that they will be able to make informed decisions on suitability and care of fabrics for all apparel. Also, there is need for learners to be exposed to newer types of sustainable fabric finishes and emerging sustainable technologies in enhancing the quality of textiles (Kadolph, 2010).

Olokocha (2012) concurs with the idea that there are rapid changes in textiles production technologies in the $21^{\text {st }}$ century. This means that the learners should be well acquainted with skills that will enable them to produce products that are user friendly to the environment. To produce A-

244 East African Journal of Education and Social Sciences (EAJESS) 2(2)239-242 
level graduates who are business minded, Olokocha further posits that the school curriculum should prepare learners who are innovative and are able to create jobs. This means that learners should be able to establish a business plan, exhibit marketing and financial management skills so that they will be able to identify markets and price goods fairly. This will aid in achieving the ZIMASSET cluster of Social Services and Poverty Eradication goals (ZIMASSET, 2013). Dale (2010) further supports the idea of project-based learning as one of the fundamental factors that can influence learners to become selfreliant.

Therefore, there is need for a curriculum which is based on creativity, innovation and knowledge that need to be nurtured and developed in learners. For example, exploring in interior design and upholstery requires a learner to be innovative in window dressings, bedding, furniture, room arrangement and wall decoration, but the current curriculum mainly focuses on apparel only (Mupfumira \& Mutsamb, 2012). In other cases, experiences are designed to help learners advance in more than one discipline such as upholstery where slipovers need to be designed for different types of furniture.

While the teaching of different skills helps learners to deepen their knowledge and make connections across disciplines, there is a need to understand how learners connect ideas within a discipline. Nordine (2011) suggests that learners need help on how to use their discipline-specific knowledge productively. This implies that when teaching textiles technology and design at A-level, skills should relate to the job market, self-reliance and entrepreneurship. This study, therefore, sought to establish the level of compatibility of the updated TTD curriculum with employment requirements in the clothing industry and entrepreneurship. Specifically, the study sought to answer the following research questions:

1. What skills and knowledge did learners acquire through the updated A-level TTD curriculum?

2. How compatible are the skills and knowledge acquired to the requirements of employment in the clothing industry and entrepreneurship?

3. To what extent did the learners acquire the intermediate skills related to Textile Technology and Design Curriculum?

\section{Research Methodology}

This section describes the methodology that was used to guide the study.

\section{Research Design}

This study used a mixed methods approach that employed both quantitative and qualitative techniques. A descriptive research design was used. The quantitative aspect investigated the acquisition of entrepreneurial skills and knowledge among learners in the updated TTD curriculum while the qualitative aspects sought to establish opinions of the teachers and factory managers on knowledge and skills developed.

\section{Population and Sampling}

The population was 120 learners and five teachers from five schools in Harare that offered TTD at the time of data collection as well as eight clothing factory managers. Three schools that had the largest number of learners were purposively selected. Forty learners who had studied the subject for at least one year were selected to participate in the study. They were given self-made questionnaires to complete. The questionnaires consisted of structured items on skills and knowledge which the learners had acquired during their study and only one item was open-ended. Three teachers who had taught TTD for at least three years were purposefully sampled for interview. In addition, three clothing factory managers were conveniently sampled based on their willingness to participate in the study Table 1 indicates the population and sampling of learners:

Table 1: Learners' Population and Sampling

\begin{tabular}{lccc}
\hline School & $\begin{array}{c}\text { Population } \\
\text { f }\end{array}$ & $\begin{array}{c}\text { Sample } \\
\text { F }\end{array}$ & \% \\
\hline School A & 40 & 15 & 37.5 \\
\hline School B & 20 & 12 & 30 \\
\hline School C & 20 & 13 & 32.5 \\
\hline Total & $\mathbf{8 0}$ & $\mathbf{4 0}$ & $\mathbf{1 0 0}$ \\
\hline
\end{tabular}

\section{Statistical Treatment of Data}

Questionnaire data was coded to enable the descriptive analysis through the Statistical Package for Social Science (SPSS) Version 16. Qualitative data from the interviews was analyzed through the thematic approach. The analysis was organized according to research questions.

\section{Ethical Considerations}

Permission to carry out the study was first obtained from the Midlands State University, Department of Applied Education at which one of the researchers 
studied and then through the Ministry of Primary and Secondary Education in Zimbabwe. Appointments to visit the schools and industries were made by the researcher before any questionnaire was distributed or any interview was conducted. Informed consent was sought from the respondents before participating in the study. Respondents were informed that no names of the schools, industry or individual participating in the study would be exposed. They were also free to withdraw from the study at any time should they so wish.

\section{Validity}

To ensure validity, the instruments were given to two experts in TTD who subjected the questionnaire and interview guide to content, construct and face validity. The experts added one item to the questionnaire and recommended some inputs for improvement of some items. Data was also double checked to reduce measurement error (Trochim, 2006). To determine the efficacy of the research instruments, a pilot test was conducted in one of the schools in Harare that was not selected for this study. Only typographical errors were identified and corrected.

\section{Reliability}

Triangulation was employed to ensure reliability. According to Denzin and Giardina (2016) triangulation is the use of two or more methods in data collection. In this study, researchers combined questionnaires and interviews data.

\section{Findings of the Study}

This section presents findings of the study based on the analysis of the data obtained from the questionnaires and interview.

\section{Demographic Data for Respondents}

Of the 40 learners in the study, 33 (83\%) were females while 7 (17\%) were males. Furthermore, $87 \%$ of the learners were between the age of 17 and 18 years while $8 \%$ were in the age group of 19 to 20 years old and $5 \%$ were in the age group of 15 to 16 years. All the three factory managers were males while all the three teachers were females. The age range of both teachers and managers was between 36 and 50 years which implies that teachers and supervisors were mature enough to be able to teach A-level learners and comfortably supervise them in the industries. Two of the teachers were holders of a Bachelor's degree in Fashion and Textiles while one had a Master's degree in Fashion and Textiles, thus, assuming that they should be competent in the delivery of TTD content at A-level.

Research Question 1: What skills and knowledge did learners acquire through the A-level TTD curriculum?

Five questionnaire items under this research question determined the specific skills and knowledge the students acquired during their study. These revolved around the student's ability to draft and use patterns, to use advanced sewing equipment, to identify fibres, to creatively use scraps of fabric and to design their own fabric (Curriculum Development and Technical Services, 2015). Students were asked to indicate with YES or NO options on their ability to draft and use patterns as reflected in table 2 .

Table 2: Pattern Drafting Skills

\begin{tabular}{lcc}
\hline Are you able to draft patterns? & f & \% \\
\hline Yes & 16 & $40.00 \%$ \\
No & 24 & $60.00 \%$ \\
Total & $\mathbf{4 0}$ & $\mathbf{1 0 0 . 0 0 \%}$ \\
\hline
\end{tabular}

Table 2 shows that 16 (40\%) of the learners had acquired skills to draft patterns while 24 (60\%) had not. Pattern drafting is an essential skill in fashion designing as designers use this skill to come up with patterns which can be used to create garments. A study by Ntiri and Apreku (2012 at a university in Ghana revealed that some fashion designers did not see the benefits of using patterns; however, the clothing design students in the study agreed that patterns helped in designing creative and professional garments. When asked further which patterns they used for sewing, 65\% of the learners in this study indicated that they used commercial patterns while $35 \%$ indicated that they used drafted patterns. Commercial patterns are readymade patterns that are sold mostly in shops while drafted patterns are made from scratch using body measurements taken from individuals. The study further revealed that $55 \%$ of the learners were aware that one can use khaki paper and pencils to make patterns while 33\% knew that computers can be used to make patterns and $12 \%$ considered draping the methods.

Two of the three teachers who were interviewed also reported that they taught using commercial patterns most of the time because they lacked pattern making skills. None of the three teachers used CAD since most schools could not afford the 
software. All clothing factory managers indicated that they preferred to employ people with basic knowledge on pattern drafting. It is therefore important that teachers be sent for short courses to learn new skills in their field of specialty so that they can in turn impart the skills to their learners.

\section{Types of Machines Used}

The learners were needed to indicate the type of skills used as shown in Table 3 which shows that $57.5 \%$ used domestic electric sewing machines, $17.5 \%$ used hand sewing machines while $25 \%$ used industrial sewing machines. This result is against the syllabus requirement which stipulates that Alevel learners should use industrial equipment so that they get operational experience which is required in clothing factories or when one wants to start a tailoring business (Curriculum Development and Technical Services, 2015).

Table 3: Type of Machines Used

\begin{tabular}{lcc}
\hline What type of sewing machines do you use? & $\mathbf{f}$ & $\mathbf{\%}$ \\
\hline Domestic electric machines & 23 & 57.5 \\
Domestic hand sewing machines & 7 & 17.5 \\
Industrial sewing machines & 10 & 25.0 \\
Total & $\mathbf{4 0}$ & $\mathbf{1 0 0}$ \\
\hline
\end{tabular}

Industrial equipment is essential as it enables one to make more garments within a shorter space of time than when domestic equipment is used. The company managers who were interviewed reported that the school leavers they had employed lacked the ability to sew fast and neatly using such industrial machines as the standard electric straight sewer and over-locker, thus, necessitating in-service training upon hiring. Thus, the use of appropriate tools for the trade are fundamental for industrialization and creation of innovative products (Ministry of Higher and Tertiary Education, 2019), but oftentimes, the costs of this machinery is beyond the reach of most schools. For that matter, Muzira and Bondai (2020) and UNESCO (2010) are of the opinion that sustainable relationships between training institutions and schools should be nurtured. School and teacher training colleges and universities should therefore work more closely together to build strong partnerships in the interest of learners' education. This partnership should start with the formulation of syllabi, through implementation and then evaluation.

\section{Fibre Identification Methods}

The learners were asked about their knowledge on methods of identifying fibres. This knowledge is essential for textile students since it is applied when selecting fabrics for specific patterns and other end uses. The responses are displayed in Table 4.

Table 4: Methods used to identify fibres

\begin{tabular}{lll}
\hline \multicolumn{1}{c}{ Method } & $\mathrm{f}$ & $\%$ \\
\hline Burning tests & 4 & 10 \\
Washing & 4 & 10 \\
Chemical or solubility tests & 5 & 12.5 \\
Ironing & 7 & 17.5 \\
Microscopic tests & 12 & 30 \\
Tearing & 8 & 20 \\
Total & 40 & 100 \\
\hline
\end{tabular}

Table 4 shows that $30 \%$ of the respondents indicated microscopic tests, $20 \%$ indicated tearing, $12.5 \%$ indicated chemical testing while burning and washing had $10 \%$ each. While microscopic, chemical and burning tests accounted for a total of $52.5 \%$ of all the responses, these tests require the use of science laboratories. Washing, ironing and tearing are physical tests which can be done without the use of complicated tools and equipment (Kadolph, 2010).Two of the teachers who were interviewed reported that they teach microscopic and solubility tests theoretically since they did not have access to science laboratories. This is tantamount to producing half-baked learners since textile testing must be carried out in carefully controlled conditions (Tortora \& Collier, 2001).

\section{Knowledge about Recycling}

Recycling of textiles is an important concept in textile studies which is linked to creating sustainable environments through creative disposal of used textiles which could otherwise be regarded as waste. Respondents were asked to indicate how they dispose of scraps which they generated when they cut fabrics as shown in Table 5:

Table 5: Methods of disposing scrap fabrics

\begin{tabular}{lcc}
\hline \multicolumn{1}{c}{ Scrap disposal method } & f & \% \\
\hline Burning & 16 & 40 \\
Dumping & 11 & 27.5 \\
Thrift work & 13 & 32.5 \\
Total & $\mathbf{4 0}$ & $\mathbf{1 0 0}$ \\
\hline
\end{tabular}


According to Table 5, $40 \%$ of respondents indicated burning, $27.5 \%$ indicated dumping while $32.5 \%$ indicated thrift work. Scrap pieces of fabric are generated as learners cut and make their practical projects. The scraps can then be used to make creative products which can be sold to raise income (Davies, Dick \& Hardy (2009). However, 67\% of the learners seemed unaware of this initiative. The lack of resourcefulness could mean that issues on disposal of textiles effluent were not well taught. Burning and dumping are practices which negatively impact the environment by emitting gaseous substances into the air and polluting landfills (Kadolph, 2010). The Environmental Management Agency (EMA) in Zimbabwe encourages industrialists to be aware of friendly environmental management standards and practices (Environmental Management Agency, 2016). It is important to note that $73 \%$ of the learners reported they were not taught about eco-friendly fibres and practices. Without this knowledge, potential business people will not be able to start their businesses. Environmental issues related to textiles and textile production should, therefore, be taught in the updated curriculum.

\section{Knowledge and Ability to Design Fabric}

Learners were asked whether they are able to design fabrics. The responses are shown in Table 6 which shows that only $15 \%$ strongly agreed, $37.5 \%$ agreed, $22.5 \%$ were neutral and $25 \%$ strongly disagreed on their ability to design fabrics. Fabric design is a key area of the updated syllabus (Curriculum Development and Technical Services, 2015) with stipulated competencies. Therefore, the combined total of those who were neutral, disagreed or strongly disagreed $(47.5 \%)$ calls for more attention to be given to this aspect of the course.

Table 6: Ability to design fabrics

\begin{tabular}{lcc}
\hline Ability to design fabrics & F & \% \\
\hline Strongly agree & 6 & 15 \\
Agree & 15 & 37.5 \\
Neutral & 9 & 22.5 \\
Strongly disagree & 10 & 25 \\
Total & $\mathbf{4 0}$ & $\mathbf{1 0 0}$ \\
\hline
\end{tabular}

The learners were further asked to indicate the methods they thought were easier to use to design fabrics as reflected in Table 6 where only 15\% strongly agreed, $37.5 \%$ agreed, $22.5 \%$ were neutral and $25 \%$ strongly disagreed.
The learners were further asked to indicate the methods they thought were easier to use to design fabrics as displayed in Table 7.

Table 7: Methods used to Design Fabrics

\begin{tabular}{lcc}
\hline Methods used to design fabrics & F & \% \\
\hline Printing & 8 & 20 \\
Dyeing & 15 & 37.5 \\
Embroidery & 8 & 20 \\
Painting & 9 & 22.5 \\
Total & $\mathbf{4 0}$ & $\mathbf{1 0 0}$ \\
\hline
\end{tabular}

Table 7 shows that $37.5 \%$ of the learners indicated that dyeing is the easiest method, followed by $22.5 \%$ who indicated painting and $20 \%$ for printing and embroidery. The fact that dyeing was the most popular method could be attributed to the cost of materials that are generally required for fabric designing. Dyeing requires the least expensive materials. In addition, learners can freely obtain natural dyeing materials from their immediate environment. Materials for printing and embroidery are more expensive than those required for dyeing. Fabric design techniques, if well taught, have potential to equip the learners with business and income generation skills. The teachers should, therefore, develop the expertise to guide the learners to acquire the fabric design skills. Resources should also be made available so that learners get adequate practice. Schools can engage the textile industries and other stakeholders to secure the needed materials. The issue of attaching learners to industries where they can be exposed to the latest technologies can also be explored (Mupfumira \& Mutsambi, 2012).

Research Question 2: How compatible are the skills and knowledge acquired with the requirements of employment in the clothing industry and entrepreneurship?

To address this research question, it was necessary to ask the learners about the business and intermediate skills they thought they had acquired during their study in order to determine the extent to which the syllabus addressed employment needs. The learners' responses are shown in Tables 8 (p. 249)

Responses are given by learners on type of business skills acquired by ticking the YES or No options. On ability to make business plans, the majority (73\%) indicated that they had not acquired such skills 
while only $27 \%$ agreed. Acquisition of business concepts is an integral part of the updated syllabus since TTD is now tied to employment creation and entrepreneurship. On whether the learners acquired knowledge for marketing the products, 93\% indicated that they had not acquired such skill while only $7 \%$ agreed. The table further reveals that only $27 \%$ agreed to have acquired knowledge on environmental impact while the majority (73\%) disagreed. Furthermore, 50\% agreed that they had acquired knowledge on income generation while the other half disagreed.

Table 8: Business skills acquired by A-level learners

\begin{tabular}{lcccc}
\hline Variable & Business Plans & Marketing Products & Environmental Impact & Income Generation \\
\hline Yes & $27 \%$ & $7 \%$ & $27 \%$ & $50 \%$ \\
No & $73 \%$ & $93 \%$ & $73 \%$ & $50 \%$ \\
\multicolumn{1}{c}{ TOTAL } & $100 \%$ & $100 \%$ & $100 \%$ & $\mathbf{1 0 0 \%}$ \\
\hline
\end{tabular}

Table 9: Intermediate skills acquired by A-level learners

\begin{tabular}{|c|c|c|c|c|c|c|c|}
\hline $\begin{array}{l}\text { Skills leant } \\
\text { and } \\
\text { acquired }\end{array}$ & $\begin{array}{l}\text { Making } \\
\text { curtains, } \\
\text { bedcovers } \\
\text { and } \\
\text { slipovers }\end{array}$ & $\begin{array}{l}\text { Interior } \\
\text { design and } \\
\text { room } \\
\text { arrangement }\end{array}$ & $\begin{array}{l}\text { Upholstery } \\
\text { making }\end{array}$ & $\begin{array}{l}\text { Self- } \\
\text { reliance } \\
\text { skills }\end{array}$ & $\begin{array}{l}\text { Employability } \\
\text { skills }\end{array}$ & $\begin{array}{l}\text { Designing } \\
\text { and } \\
\text { fashion } \\
\text { illustrating } \\
\text { skills }\end{array}$ & $\begin{array}{l}\text { Entrepreneurs } \\
\text { hip skills }\end{array}$ \\
\hline $\begin{array}{l}\text { Strongly } \\
\text { Agree }\end{array}$ & $12 \%$ & $10 \%$ & $12 \%$ & $10 \%$ & $5 \%$ & $16 \%$ & $18 \%$ \\
\hline Agree & $12 \%$ & $10 \%$ & $20 \%$ & $8 \%$ & $24 \%$ & $24 \%$ & $5 \%$ \\
\hline Neutral & $23 \%$ & $27 \%$ & $20 \%$ & $34 \%$ & $24 \%$ & $34 \%$ & $29 \%$ \\
\hline Disagree & $25 \%$ & $30 \%$ & $20 \%$ & $16 \%$ & $29 \%$ & $18 \%$ & $24 \%$ \\
\hline \multicolumn{8}{|l|}{ Strongly } \\
\hline Disagree & $28 \%$ & $23 \%$ & $23 \% \%$ & $32 \%$ & $18 \%$ & $8 \%$ & $24 \%$ \\
\hline Total & $100 \%$ & $100 \%$ & $95 \%$ & $100 \%$ & $100 \%$ & $100 \%$ & $100 \%$ \\
\hline
\end{tabular}

These findings may suggest that the concepts in table 8 were not well taught although it is part of the syllabus. Through interview, the TTD teachers reported that they lacked requisite content on business and entrepreneurship skills because they did not cover the concepts in their modules at college. Therefore, lack of students' competency was a result of teacher's limited knowledge on the concepts.

Research Question 3: To what extent did the learners acquire the intermediate skills related to Textile Technology and Design Curriculum?

Table 9 shows results on the intermediate textile entrepreneurship skills acquired by the learners as stipulated in the A-level TTD learner exit expectation (Curriculum Development and Technical Service, 2015). Results indicate that only $24 \%$ of the learners agreed or strongly agreed that they had acquired skills necessary for making curtains, bedcovers and slip covers. The table also indicates that $20 \%$ of the learners agreed or strongly agreed that they had acquired skills on interior design and room arrangements. Furthermore, 32\% agreed or strongly agreed that they had acquired skills on upholstery making. Only $18 \%$ of the learners agreed or strongly agreed to have acquired self-reliance skills while only $29 \%$ agreed or strongly agreed to have acquired employability skills. While $40 \%$ of the learners agreed or strongly agreed to have acquired designing and fashion illustrating skills, only $23 \%$ of the learners agreed or strongly agreed to have acquired entrepreneurial skills. Therefore, majority of the learners were neutral, disagreed or strongly disagreed with the items in table 9.

\section{Conclusions and Recommendations}

This section presents the conclusions of the study, followed by the recommendations: 


\section{Conclusions}

The study concludes that the skills and knowledge acquired by A-Level TTD learners were limited as learners did not acquire adequate essential concepts in designing, pattern making, computer aided designing, use of industrial sewing equipment and business enterprise which are critical for business or employment in the clothing industry. It is also concluded that while some study areas are compatible with the requirements of the clothing industry and entrepreneurship, the content is not well taught as teachers were not proficient with new skills and knowledge in the updated syllabus including entrepreneurship.

\section{Recommendations}

A more skills based curriculum is recommended. Increased collaboration between the Curriculum Development Technical Services, schools and teacher training institutions, ZIMSEC, the clothing/textile industry and other relevant stakeholders is vital in order to effectively implement a school curriculum that is more diverse and skills based. TTD teachers need in-service training in business and entrepreneurship skills for them to effectively facilitate the correct learning of the business skills.

\section{Reference}

Aldrich, W. (2015). Metric pattern cutting for women's wear, $5^{\text {th }}$ ed. Oxford: Blackwell.

Association of Graduate Careers Advisory Services. (AGCAS). (2016/ 2017). Careers Fairs Survey - Research Report. London.

Curriculum Development and Technical Services. (2015). Textile Technology and Design Syllabus. Forms 5-6. 2015 - 2022. Harare, CDTS.

Dale, R. (2010). Education, Training and Employment: Towards a new vocationalism? London: Pergamon.

Denzin, N. K., \& Giardina, M. D. (Eds.). (2016). Qualitative inquiry and the conservative challenge: Confronting methodical fundamentalism. USA, Routledge.

Dickerson, P. (2003). The use of technology in the textile industry. New Jersey: Data Cooperation.

Environmental Management Agency (EMA) (2016). EMA Annual Report. Harare, Zimbabwe.
Kadolph, S. J. (2010). Textiles. $11^{\text {th }}$ ed. New Jersey, Pearson Education.

Marume, M. (June 5, 2012). Entrepreneurship policy theory and practice. $<$ http//entrepreneurship\&education.org.w/I ndex.php.>

Ministry of Higher and Tertiary Education. (2019). Education 5.0. Doctrine for the modernization and industrialization of Zimbabwe through education, science and technology development to achieve Vision 2030. Bindura University of Science and Education (BUSE).

Mlambo, A. (2017). ZimAsset, a failed economic policy. Retrieved from newsday.co.zw

Mupfumira, I. E. \& Mutsambi, T. P. (2012). An evaluation of demonstration and industrial attachment as strategies in implementing clothing curriculum: A case of a Masvingo Polytechnic in Zimbabwe. Journal of African Studies and Development, Vol 4(4), pp. 114121. DOI: $10.5897 / J A S D 11.067$.

Murwira, A. (2019). Towards revitalising the roles of Universities in development [Zimbabwe]. Retrieved from https://www.ruforum.o rg/AGM2 019/sit es/d efault/files/ HON_MINISTER_PR OF_MURWIR A_SP EE CH.pdf.

Muzira, D. M. \& Bondai, B. M. (2020). Perception of educators towards the adoption of Education 5.0: A Case of a State University in Zimbabwe. East African Journal of Education and Social Sciences. EAJESS, Vol. 1, No. 2, pp. 43-53. ISSN: 2714-2132 (Online), 2714-2183 (Print), DOI: https://doi.org/10.46606/eajess2020v01i02. 0020URL: http://eaj.

Nkomo, M. G. (2016). Curriculum Implementation Change and Innovation, Module EA3AD303. Harare, University of Zimbabwe: The Center for Distance Education.

Nordine, J. C. (2011). Motivating Calculus based Kinematics Instructions with Super Mario Bros, 49 (380), pp. 380-382. Doi: 10119/1, 3628271.

Ntiri, J. A. \& Apreku, V. (2012). Layouts and effective creation of female garment designs in Ghananian clothing industry. Arts and Design Studies, 4, 24. ISSN 2224-6061 
(Paper) ISSN 2225-059X (Online). Tortora, P. G. \& Collier, B. J. (2001). Understanding www.iiste.org. Textiles. New York: Macmillan Publishing.

Nziramasanga, C. T. (1999). Zimbabwe report of the presidential commission of inquiry into education and training. Harare: Government Printers.

Olokocha, C. C. (2012). Vocational technical education in Nigeria: Challenges and the way forward. Business Management Dynamics 2. (6). 1-8.

Pearson, R. (2003). Skills for knowledge economy: Issues and challenges in VET reform in Lebanon. Washington, D. C; World Bank.

Trochim, W. M. K. (2006) Measurement error. Retrieved from http://www.soc ialrese archm ethods.net.

UNESCO. (2010). EFA global monitoring report 2010: Reaching the marginalized. Paris: UNESCO.

ZIMASSET. (2013). Zimbabwe Agenda for sustainable socio-economic transformation: Towards an empowered society and a growing economy. October 2013 -December 2018. Harare: Government of Zimbabwe.

Stevenson, L. (2012). The entrepreneurship of women. Business management, 24, 30-31. 